Acta Universitatis Wratislaviensis No 3705

PRAWO CCCXX Wrocław 2016

DOI: $10.19195 / 0524-4544.320 .3$

AGNIESZKA KANIA

Uniwersytet Zielonogórski

e-mail:a.kania@wpa.uz.zgora.pl

\title{
Sprawiedliwość kary z perspektywy ustawowych wskazań jej wymiaru. Rozważania na tle kodeksu karnego
}

\section{Wprowadzenie w problematykę}

Problematyka sprawiedliwości, jako swoiste signum temporis, stanowi przedmiot rozważań nie tylko myśli filozoficzno-etycznej, psychologicznej czy socjologicznej, ale również obiekt żywego zainteresowania reprezentantów nauk prawnych ${ }^{1}$. Trafnie więc oceniono w piśmiennictwie, że „sprawiedliwośćc to słowo, którego wydźwięk i odczucie nie pozostawia nikogo obojętnym na jego znaczenie $^{2}$. Stąd też można dopowiedzieć, że również wszelkie poczucie niesprawiedliwości będzie odbierane przez wielu jako krzywda sprawiająca szczególnie bolesną dolegliwość ${ }^{3}$.

„Bogata aura skojarzeniowa”, która pojawia się wokół sprawiedliwości ${ }^{4}$, powoduje jednak, że próba zdefiniowania tego pojęcia ${ }^{5}$ okazuje się prawdziwym

1 Por. T. Orczykowski, Szkoła psychologiczna w prawie, Torun 2007, s. 56-57. O pojęciu i sposobach pojmowania sprawiedliwości zob. m.in. Arystoteles, Etyka nikomachejska, Warszawa 2011, s. 79; Z. Ziembiński, O pojmowaniu sprawiedliwości, Lublin 1992, s. 18; K. Ajdukiewicz, O sprawiedliwości, [w:] idem, Język i poznanie, t. 1, Warszawa 1960, s. 365; J. Karp, Sprawiedliwość społeczna. Szkice ze współczesnej teorii konstytucjonalizmu i praktyki polskiego prawa ustrojowego, Kraków 2004, s. 69; M. Zalewska, Racjonalne koncepcje sprawiedliwości w ocenie Hansa Kelsena, [w:] Rozdroża sprawiedliwości we współczesnej myśli filozoficznoprawnej, red. B. Wojciechowski, M.J. Golecki, Toruń 2008, s. 53 n.

2 Por. S.J. Karolak, Sprawiedliwość. Sens prawa. Eseje, Kraków 2005, s. 9.

3 Ibidem.

${ }^{4}$ Por. M. Augustyniak, Sprawiedliwość w myśli Arystotelesa, [w:] Sprawiedliwość. Wybrane koncepcje, red. B. Kruszewska, P. Polaczuk, L. Świto, Olsztyn 2010, s. 5.

5 Por. M. Łoś-Bobińska, Zasady wymiaru sprawiedliwości w świetle badań ankietowych, „Etyka” 1968, nr 3, s. 162; por. także T. Kaczmarek, Sędziowski wymiar kary w Polskiej Rzeczpospolitej 
wyczynem. Spośród wszystkich ,pojęć szacownych” pozostaje ono wprawdzie jednym z najważniejszych, ale jednocześnie przynależy do kategorii najbardziej mglistych ${ }^{6}$. Z istotą wyrażonych uwag korespondują więc słowa, że: „Sprawiedliwość to wspaniałe zawołanie, póki pozostaje nieruchoma na swym wyniosłym cokole ideowym, ale gdy chcieć sprowadzić ją stamtąd na ziemię i dać jej praktyczną misję regulowania stosunków międzyludzkich — okazuje się, że brak zgody na jedno jej znaczenie"7.

Zgodnie z podjętą w niniejszym opracowaniu problematyką, dalsze rozważania zostaną poświęcone prawnokarnej sprawiedliwości karania ${ }^{8}$.

\section{Rola dyrektywy stopnia winy oraz pozytywnej prewencji ogólnej w procesie wymiaru kary sprawiedliwej — uwagi na tle założeń kodeksu karnego z 1997 r.}

Przyjmując za punkt wyjścia, że prawo karne wykazuje ścisły związek ze sprawiedliwością, a najwłaściwszym dla niej miejscem jest sprawiedliwość karania ${ }^{9}$, należałoby w konsekwencji stwierdzić, iż odpowiedź na nurtujące od dawna pytanie: „Jaką karę powinny wymierzać sądy?” pozostaje de facto niezmienna ${ }^{10}$. Trafnie zatem ocenili twórcy obowiązującej kodyfikacji, że jednym z podstawowych warunków dla procesu kształtowania świadomości prawnej społeczeństwa jest: ,[...] orzekanie kar (środków) odbieranych jako reakcja sprawiedliwa"11. Wychodząc zaś naprzeciw konkretnym oczekiwaniom praktyki wymiaru

Ludowej w świetle badań ankietowych, Wrocław 1972, s. 70-71.

6 Por. A. Perelman, O sprawiedliwości, przeł. W. Bieńkowska, Warszawa 1959, s. 22.

7 Por. M. Szerer, Problematyka spolecznego oddziatywania kary, „Państwo i Prawo” 1974, z. 5, s. 19. W prezentowanej wypowiedzi autor jednocześnie zaznaczył, że: „[...] słynne cyceronowe sformułowanie, że iustitia suum cuique distribuit, okazuje się zwodnicze, bo jak przydzielać każdemu, co mu się należy, skoro nie wiadomo właśnie, co się komu należy".

${ }^{8}$ Sygnalizowane $\mathrm{w}$ ten sposób kontrowersje interpretacyjne potwierdzają już prima facie cztery teoretyczne - a jednocześnie odmienne w swej treści — formuły, objaśniające „sprawiedliwościowy” sens decyzji sądowych. Por. J. Wróblewski, Wartości a decyzja sądowa, Wrocław 1973, s. 185-189.

9 Por. A. Grześkowiak, Funkcje kary w świetle projektów zmian kodeksu karnego, [w:] Ius et Lex. Księga jubileuszowa ku czci Profesora Adama Strzembosza, red. A. Dębiński, A. Grześkowiak, K. Wiak, Lublin 2002, s. 47-48. Autorka jednocześnie zwróciła uwagę, że: „Żródłem sprawiedliwości karnej winna być przyrodzona godność człowieka i szacunek dla każdej ludzkiej istoty”.

10 Por. A. Sylwestrzak, Filozofia sprawiedliwości Hansa Kelsena, [w:] Doktryny polityczne i prawne u progu XXI wieku, red. M. Maciejewski, M. Marszał, Wrocław 2002, s. 460-461.

11 Nowe kodeksy karne z 1997 r. z uzasadnieniem, Warszawa 1997, s. 153. Warto zauważyć, że z powyższego brzmienia nie wynika wprost, czy chodzi o subiektywny, czy obiektywny odbiór pojęcia „sprawiedliwości”. 
sprawiedliwości w tym zakresie, w Uzasadnieniu do projektu kodeksu karnego wspomniani kodyfikatorzy udzielili wskazania, że dolną granicę konkretnej kary wyznaczają w zasadzie potrzeby stabilizacji porządku prawnego utożsamianego z pozytywną prewencją ogólną, natomiast górną wyznacza (limituje) zasada winy. W tych granicach, jak podkreślono, sąd może wymierzyć karę według potrzeb prewencji indywidualnej ${ }^{12}$.

Powyższa wypowiedź, istotna niewątpliwie z perspektywy sprawiedliwego karania, nasuwa jednakże pewne wątpliwości. Przede wszystkim nie wynika z niej w sposób klarowny, czy wspomniane, „graniczne” dyrektywy współwyznaczają rodzaj i rozmiar kary, czy też ich znaczenie sprowadza się tylko do funkcji limitującej wymiar kary ${ }^{13}$. Poza tym w treści przytoczonego fragmentu Uzasadnienia całkowicie zignorowano znaczenie dyrektywy stopnia społecznej szkodliwości czynu w procesie sądowego wymiaru kary. Równie poważne zastrzeżenia wzbudzał także sam „,dyrektywalny schemat” odpowiadający za wyznaczenie tzw. ogólnych granic wymiaru kary. Wysunięte pod jego adresem uwagi odnosiły się zarówno do dyrektywy ogólnoprewencyjnej, jak również dyrektywy stopnia winy.

Negując zaproponowany przez twórców kodeksu karnego sposób określenia dolnej granicy wymiaru kary, w doktrynie przedmiotu wyrażono pogląd, że podstawową rolę w tym zakresie powinna odgrywać — prima facie niedoceniona w tekście Uzasadnienia — dyrektywa stopnia społecznej szkodliwości czynu ${ }^{14}$. Przypisując zaś wskazaniu ogólnoprewencyjnemu dekoracyjny charakter, uznano, że dyrektywa ta odzwierciedla jedynie ,,piękne hasła”, które wprawdzie ,ładnie brzmią" ${ }^{15}$, ale nie nadają się do przełożenia na język praktyki ${ }^{16}$. Utożsamienie przez twórców kodeksu karnego ogólnoprewencyjnego przesłania z dążeniem do stabilizacji norm trudno bowiem uznać za miarodajną wskazówkę, w oparciu o którą sąd mógłby: „[...] wyrobić sobie chociażby bardzo ogólny pogląd — jaka co do rodzaju i wysokości kara mogłaby dopiero stabilizować normy, a która tej właściwości stabilizującej byłaby już pozbawiona"17. Enigmatyczna pozostawała również i ta część wykładni dyrektywy prewencji ogólnej, w której, eksplikując jej istotę, autorzy kodeksu odwołali się do czynników niezależnych od sądu orze-

12 Ibidem.

13 W ocenie M. Dąbrowskiej-Kardas spór ten może w istocie wydawać się pozorny. Por. M. Dąbrowska-Kardas, Analiza dyrektywalna przepisów części ogólnej kodeksu karnego, Warszawa 2012, s. 266-267, 270 i literatura tam podana.

14 L. Gardocki, Prawo karne, Warszawa 1999, s. 177.

15 W. Mącior, W sprawie reformy prawa karnego, „Państwo i Prawo” 1991, z. 10, s. 94.

16 T. Bojarski, Uwagi o dalszych projektowanych zmianach części ogólnej kodeksu karnego, [w:] Nowe prawo karne po zmianach, red. T. Bojarski, E. Skrętowicz, Lublin 2002, s. 62.

17 T. Kaczmarek, O pozytywnej prewencji ogólnej w ujęciu projektu kodeksu karnego z 1994 r., „Palestra” 1995, nr 3-4, s. 69; por. także H.H. Jescheck, Strafgesetzbuch. Einführung, München 1987, s. 12; H.H. Jescheck, T. Weigend, Lehrbuch des Strafrechts. Allgemeiner Teil, Berlin 1996, s. 881; B. Szamota-Saeki, Pozytywna prewencja ogólna w nauce niemieckiej, „Archiwum Kryminologii” 2003-2004, t. 27, s. 51; por. A. Zoll, Założenia polityki karnej w projekcie kodeksu karnego, „Państwo i Prawo" 1994, z. 5, s. 7. 
kającego. Akcentowanie przy objaśnianiu sensu ogólnoprewencyjnego oddziaływania kary wykrywalności czynów zabronionych, jak również nieuchronności ponoszenia odpowiedzialności karnej za popełnione przestępstwo ${ }^{18}$ wykracza niewątpliwie poza sferę działalności orzeczniczej sądu, wykazując za to ścisły związek ze sprawnym funkcjonowaniem organów ścigania ${ }^{19}$. Równie spekulatywno-intuicyjny wydaje się ten fragment Uzasadnienia, w którym starano się dowieść, iż „odwoływanie się” przez sąd do poglądów opinii publicznej (stanowiących wyznacznik poziomu odczuwalnej przez społeczeństwo satysfakcji wynikającej z wymierzanych kar) stanowiłoby adekwatne kryterium dla określenia kary akceptowalnej z punktu widzenia założeń ogólnoprewencyjnych ${ }^{20}$. Za wątpliwą, zwłaszcza z perspektywy empirycznej, należałoby także uznać propozycję, w ramach której podniesiono, że o ustaleniu rodzaju i rozmiaru kary uwzględniającej założenia ogólnoprewencyjne mogłyby decydować dwa zasadnicze czynniki:

1) postawy oraz poglądy społeczeństwa, w oparciu o które można by wskazać prawdopodobieństwo popełniania przestępstw oraz

2) warunki egzystencjonalne danego środowiska, które inicjują bądź pogłębiają konflikty z prawem² ${ }^{21}$.

Od pojawiających się kontrowersji nie pozostawała również wolna koncepcja, w świetle której dowodzono, że czynniki wpływające na stopień niebezpieczeństwa (obecnie stopień społecznej szkodliwości) okazują się miarodajne dla oceny wymiaru kary z punktu widzenia wskazania ogólnoprewencyjnego ${ }^{22}$. Wydaje się bowiem, że dokonanie tak prostego przełożenia kwantyfikatorów społecznego niebezpieczeństwa czynu na treść dyrektywy prewencji ogólnej okazuje się zabiegiem wprost niemożliwym. Przykładowo trudno byłoby m.in. na podstawie okoliczności odwołującej się do „rozmiaru wyrządzonej przez sprawcę szkody” uzyskać jakąkolwiek wartość prognostyczną dotyczącą określonego środowiska społecznego ${ }^{23}$. Ponadto miarodajnej wartości dla wskazania ogólnoprewencyjnego nie stanowi również kryterium nagminności popełniania przestępstw. Przy współcześnie zaaprobowanej aksjologii karania można wręcz przypuszczać, że już prima facie formułowanie tego rodzaju propozycji interpretacyjnych mogłoby wzbudzać poważne zastrzeżenia merytoryczne ${ }^{24}$. W literaturze przedmiotu pod-

18 J. Kulesza, Negatywna prewencja generalna, „Państwo i Prawo” 2011, z. 1, s. 42.

19 Nowe kodeksy karne..., s. 153.

${ }^{20}$ K. Buchała, Głos w dyskusji, [w:] Problemy reformy prawa karnego, red. T. Bojarski, E. Skrętowicz, Lublin 1993, s. 339-340.

${ }^{21}$ K. Buchała, Dyrektywy sadowego wymiaru kary, Warszawa 1964, s. 81-82.

${ }^{22}$ K. Buchała, Ogólne dyrektywy sadowego wymiaru kary w projekcie kodeksu karnego, „Państwo i Prawo" 1969, z. 2, s. 312; idem, Społeczne niebezpieczeństwo czynu jako dyrektywa sądowego wymiaru kary, „Krakowskie Zeszyty Prawnicze” 1970, nr 3, s. 145; por. także A. Zoll, Stopień spotecznego niebezpieczeństwa czynu jako dyrektywa wymiaru kary, „Nowe Prawo” 1969, nr 6, s. 940, a także Uzasadnienie do projektu rzadowego zmiany k.p.k. Reforma procedury karnej, „Demokratyczny Przegląd Prawniczy" 1949, nr 6-7, s. 10.

23 J. Giezek, Okoliczności wplywające na sędziowski wymiar kary, Wrocław 1989, s. 167-168.

24 M. Płatek, Rola prawa karnego wykonawczego w zapobieganiu przestępczości, „Studia Iuridica" 2000, t. 38, s. 111.

Prawo 320, 2016

(C) for this edition by CNS 
niesiono wręcz, iż poszukiwanie wzajemnych powiązań pomiędzy kryterium nagminności a treścią wskazania ogólnoprewencyjnego okazuje się podwójnie zawodne. Taki kierunek wykładni nie przyniósłby bowiem spodziewanego rezultatu poznawczego niezależnie od tego, czy prewencja ogólna zostałaby utożsamiona z elementem odstraszania, czy też jej treść powiązanoby z konstruktywnym wpływem sankcji karnej na postawy społeczne. O ile w pierwszym przypadku wzajemne relacje nagminności z prewencją ogólną uruchamiałyby rażący tok prymitywnego rozumowania, zgodnie z którym jednostka jest traktowana nie jako cel, lecz jako środek realizujący określony kierunek polityki kryminalnej, o tyle w drugim przypadku odwoływanie się do nagminności mogłoby zostać wykorzystane jako pozaempiryczny instrument medialnej manipulacji służący wzbudzeniu poczucia niebezpieczeństwa w odbiorze jednostkowym ${ }^{25}$. Ponadto o dalszych trudnościach związanych z doborem kryteriów, relewantnych z perspektywy wykładni celu ogólnoprewencyjnego, świadczy także wyrażony w orzecznictwie pogląd, w którym nie tylko zwrócono uwagę, że komentowana dyrektywa nie powinna być rozpatrywana ,z momentu popełnienia przestępstwa" ${ }^{26}$, lecz także podniesiono, iż okoliczności, tradycyjnie oceniane z punktu widzenia prewencji indywidualnej, jak np.: naprawienie szkody lub staranie się o jej naprawienie, podejmowanie innego rodzaju zachowań po popełnieniu przestępstwa, zwłaszcza pojednanie się z pokrzywdzonym, okazują się czynnikami równie istotnymi z punktu widzenia oddziaływania ogólnoprewencyjnego ${ }^{27}$. W zaproponowanym ujęciu dostrzega się jednakże pewną nieścisłość. Wydaje się bowiem, że w prezentowanym stanowisku Sąd Najwyższy powinien dokonać bardziej precyzyjnego stwierdzenia, podnosząc jednoznacznie, że okoliczności indywidualnoprewencyjne istotne dla wymiaru kary także z punktu widzenia prewencji ogólnej dotyczą określonej kategorii zachowań sprawcy, mianowicie jedynie tych, które miały miejsce po popełnieniu przestępstwa. Analizując cytowane orzeczenie (zwłaszcza w kontekście przyszłego, ewentualnego odwoływania się do jego postanowień), wypadałoby więc zaznaczyć, że z perspektywy ogólnoprewencyjnej nie należy w szczególności rozważać sposobu życia sprawcy, skoro jest on sądzony za czyn, a nie za naganny tryb własnej egzystencji ${ }^{28}$. Z poglądem tym koreluje zresztą powszechnie aprobowane stanowisko, iż: „Wymiar kary należy odnieść przede wszystkim do czynów oskarżonych, a nie ich życiorysów, bo prawo karne jest »prawem czynu«, a nie — jak prawo nieletnich — »prawem sprawcy «"29.

25 W. Wróbel, Nagminność przestępstwa w systemie dyrektyw sądowego wymiaru kary, „Państwo i Prawo" 1990, z. 3, s. 64-65.

26 Por. Wyrok Sądu Apelacyjnego w Krakowie z dnia 17 grudnia 2009 r., II AKa 223/09, „Krakowskie Zeszyty Sądowe” 2010, nr 2, poz. 32.

27 Por. Wyrok Sądu Najwyższego z dnia 22 października 1981 r., II KR 223/81, OSNPG 1982, nr 6, poz. 77; por. także M. Królikowski, S. Żółtek, [w:] Kodeks karny. Część ogólna. Komentarz do art. 32-116, red. M. Królikowski, R. Zawłocki, t. 2, Warszawa 2010, s. 280.

${ }_{28}$ M. Królikowski, S. Żółtek, op. cit., s. 284.

29 Wyrok Sądu Apelacyjnego w Krakowie z dnia 28 grudnia 1990 r., II AKr 9/90, „Krakowskie Zeszyty Sądowe" 1991, nr 1, poz. 15.

Prawo 320, 2016

(C) for this edition by CNS 
Traktowanie dyrektywy pozytywnej prewencji generalnej jako wyznacznika dolnej granicy wymierzanej kary wzbudza zastrzeżenia również z innego względu. Abstrahując wprawdzie od dalszych wątpliwości związanych z możliwością wyznaczenia ogólnoprewencyjnych kwantyfikatorów, należy zwrócić uwagę, iż zgodnie z powszechnie aprobowanym założeniem sens kary kryminalnej odzwierciedla zadana za jej pośrednictwem dolegliwość. Dostrzegając de lege lata normatywny charakter wspomnianej dolegliwości, wyrażonej in principio w art. $53 \S 1$ k.k., należałoby więc w tym miejscu zastanowić się, czy w ,programie" pozytywnej prewencji generalnej odpowiedzialnej, zgodnie z intencją twórców kodeksu karnego, za wyznaczenie dolnej granicy kary zawiera się wspomniany element? W ocenie autorów obowiązującej kodyfikacji istota pozytywnie prewencyjnego oddziaływania kary skupia się bowiem na inkulturacji oraz na sile perswazji przekonującej, że państwo reaguje na fakt złamania normy sankcjonowanej, co w konsekwencji przemawiałoby za udzieleniem negatywnej odpowiedzi na sformułowane powyżej pytanie ${ }^{30}$. Skoro więc pozytywna prewencja ogólna ma spełniać funkcję: stabilizującą obowiązywanie norm prawnych; uczącą ich przestrzegania; wpajającą szacunek dla obowiązującego prawa; jak również przekonującą, że państwo reaguje na każdy fakt złamania normy sankcjonowanej ${ }^{31}$, to niewątpliwie trudno byłoby wyróżnić powiązania zachodzące pomiędzy pozytywnie prewencyjnie zorientowanym wymiarem kary a dolegliwością, stanowiącą de facto jej istotę 32 .

Pozostając na płaszczyźnie krytyki wysuwanej pod adresem „ogólnych ram” dla sądowego wymiaru kary, należałoby także wspomnieć, iż równie negatywne oceny skierowano wobec limitującego ujęcia drugiej z ,granicznych” dyrektyw — dyrektywy stopnia winy. Określając komentowaną regulację mianem „kardynalnego błędu," starano się przede wszystkim wykazać, iż takie ujęcie redakcyjne nie pozwala na uznanie stopnia winy za podstawowy, ale jedynie za ograniczający wskaźnik dla sądowego wymiaru kary ${ }^{33}$. Wobec powyższego uznano wręcz, że przyjęte unormowanie jest niezgodne z samą ideą kary sprawiedliwej, wymagającą zachowania odpowiedniości pomiędzy zastosowaną sankcją karną a winą sprawcy $^{34}$. W dalszych uwagach podniesiono także, że zdegradowanie winy do

30 B. Janiszewski, Dolegliwość jako element współczesnej kary kryminalnej, [w:] Przestępstwo - kara - polityka kryminalna. Problemy tworzenia i funkcjonowania prawa. Ksiega jubileuszowa z okazji 70. rocznicy urodzin Profesora Tomasza Kaczmarka, red. J. Giezek, Kraków 2006, s. 305.

${ }^{31}$ K. Buchała, [w:] K. Buchała, A. Zoll, Kodeks karny. Część ogólna. Komentarz, Kraków 2001, s. 414-415.

32 Por. W. Dadak, Dolegliwość sankcji karnej w czasie orzekania oraz w okresie wykonywania kary, [w:] Państwo prawa i prawo karne. Ksiega Jubileuszowa Profesora Andrzeja Zolla, red. P. Kardas, T. Sroka, W. Wróbel, t. 2, Warszawa 2012, s. 844.

33 Por. W. Mącior, Założenia polityki karnej w projekcie kodeksu karnego z 1995 r., „Przegląd Sądowy" 1996, nr 9, s. 72; por. także W. Wolter, Zasady wymiaru kary w kodeksie karnym z 1969 r., „Państwo i Prawo” 1967, nr 10, s. 508.

34 M. Cieślak, Polskie prawo karne. Zarys systemowego ujęcia, Warszawa 1994, s. 460. 
czynnika limitującego wysokość stosowanej sankcji prowadzi w istocie do wątpliwego wniosku zakładającego, iż stosowanie środków prawnokarnych uzasadniają wyłącznie prewencyjne potrzeby karania ${ }^{35}$.

Zaprezentowany kierunek wykładni spotkał się jednakże z krytyczną odpowiedzią w literaturze przedmiotu. Zarzucając powyższej propozycji pominięcie sui generis multizadaniowości kary, podkreślono dosadnie, iż „każde” (a nie w istocie tylko jedno ze wskazań ustawowych) zasługuje na odrębną uwagę przy wymiarze kary oraz że ,każde” z nich ma do spełnienia inną rolę w tym procesie $^{36}$. Zarzucony ustawodawcy ,kardynalny błąd” przy sformułowaniu art. 53 $\S 1$ k.k. próbowano ponadto zneutralizować stwierdzeniem ${ }^{37}$, że wzgląd na to, aby dolegliwość kary nie przekroczyła stopnia zawinienia i wymierzenie sprawcy kary współmiernej do winy, nie pozostają względem siebie w kontradykcji. W ten sposób starano się więc raz jeszcze wykazać, iż ograniczenie roli winy do limitowania wymiaru kary „od góry” nie pozostaje w sprzeczności z koncepcją kary sprawiedliwej. Sytuacja taka zachodziłaby bowiem tylko wówczas, jeżeli wina stanowiłaby jedyny wyznacznik odpowiadający za sprawiedliwy wymiar kary ${ }^{38}$. Spoglądając więc na wskazany problem „z głębszej perspektywy poznawczej”, należałoby przyjąć, że ustawowe wymaganie, aby: „, [...] kara nie przekraczała granic winy sprawcy, jest niczym innym jak właśnie racjonalizacją celowościowo zabarwionej odpłaty, przy której sąd związany postulatem, aby wymierzone przez niego kary w swojej dolegliwości nie przekraczały stopnia zawinienia, zobowiązany w istocie do wymiaru kary sprawiedliwej, ukierunkowany został przez projektodawcę na uwzględnienie także przy wymiarze kary celu zaspokojenia społecznego poczucia sprawiedliwości"39. Zaspokojenie tego poczucia stanowiłoby ,[...] właśnie odrębny i ważny cel prawidłowo rozumianej idei sprawiedliwej odpłaty"40. W konsekwencji wypadałoby zatem stwierdzić, że wymaganie, aby: ,[...] dolegliwość kary nie przekroczyła stopnia zawinienia i dawkowanie kary współmiernej do winy nie wykluczają się przecież. [...] W praktyce [...] bardzo często kara nieprzekraczająca dolegliwością progu wyznaczonego stopniem winy będzie jednocześnie do winy tej współmierna, chyba że inne istotne względy przemawiają za jej złagodzeniem" ${ }^{41}$.

35 W. Mącior, Kara dostosowana do stopnia winy sprawcy, „Rzeczpospolita”, 28.05.2003 r.

36 A. Zoll, O reformie prawa karnego (W odpowiedzi W. Maciorowi), „Państwo i Prawo” 1992, nr 1, s. 98.

37 K. Skowroński, Nie bójmy się zaufać sędziom, [w:] „Rzeczpospolita”, 25.07.2003 r.

38 Ibidem.

39 T. Kaczmarek, Ogólne dyrektywy wymiaru kary jako problem kodyfikacyjny, [w:] Problemy reformy prawa..., s. 52-53.

40 Ibidem.

41 J. Giezek, [w:] J. Giezek, N. Kłączyńska, G. Łabuda, Kodeks karny. Część ogólna. Komentarz, red. J. Giezek, Warszawa 2012, s. 383; por. także A. Marek, Prawo karne, Warszawa 2003, s. 335; T. Bojarski, Społeczna szkodliwość czynu i wina w projekcie k.k., [w:] Problemy kodyfikacji prawa 
Z dotychczasowych rozważań wynika zatem, iż wysuwany w doktrynie zarzut niewłaściwego wyeksponowania czynnika odpłaty w aktualnej treści art. $53 \S 1$ k.k. wydaje się nieuzasadniony. Warto jednak podkreślić, że obecne nawiązanie do tej racjonalizacji zostało oparte na zgoła odmiennych założeniach w porównaniu do dawnych, retrybutywnych koncepcji kary. W obowiązującej redakcji kodeksu karnego limitująca dyrektywa stopnia winy nie jest bowiem jedynie racją wymiaru kary ${ }^{42}$, co niewątpliwie przemawia przeciwko transcendentnemu pojmowaniu idei „współczesnego" odwetu ${ }^{43}$.

Powyższe ustalenia prowadzą do wniosku, że wykładnia tzw. „granicznych” podstaw sądowego wymiaru kary wzbudza liczne kontrowersje nie tylko na płaszczyźnie teorii, lecz także na gruncie praktyki stosowania prawa. Złożoność niniejszej problematyki nie ułatwia tym samym odpowiedzi na nurtujące pytanie — a jeśli tak, to które z ustawowych wskazań pozwalają na wymierzenie sprawcy kary sprawiedliwej ${ }^{44}$ ?

\section{Sprawiedliwość kary — próba modelowego ujęcia}

Próbując odpowiedzieć na postawione powyżej pytanie, należałoby w pierwszej kolejności odnotować, iż w doktrynie przedmiotu wyrażono m.in. przekonanie, że sens kary sprawiedliwej odzwierciedlają dwie ogólne dyrektywy sądowego jej wymiaru, mianowicie dyrektywa stopnia winy oraz dyrektywa stopnia społecznej szkodliwości czynu ${ }^{45}$. W zaprezentowanym, de facto bardzo wąskim ujęciu (strictissimo sensu), stwierdzono, że czynniki prognostyczne związane z prewencją nie łączą się z kryterium sprawiedliwościowej koncepcji kary. Powyższe przekonanie uzasadniano zaś tym, że wspomniane względy prewencyjne nie odwołują się do preferowanej w tym zakresie formuły „każdemu według ujemnej wartości jego czynu”, lecz bazują na ustaleniu „każdemu według jego

karnego. Księga ku czci Profesora Mariana Cieślaka, red. S. Waltoś, Kraków 1993, s. 81; V. Konarska-Wrzosek, Dyrektywy wyboru kary w polskim ustawodawstwie karnym, Torun 2002, s. $81 \mathrm{n}$.

42 A. Zoll, Wina i kara, „Nauka” 2004, nr 1, s. 45.

43 K. Buchała, Problemy wyboru wiodacej dyrektywy wymiaru kary wedtug art. 54 projektu kodeksu karnego z 1995r., „Przegląd Prawa Karnego” 1995, nr 13, s. 8, 13; por. także M. Cieślak, O węzłowych pojęciach zwiąanych z sensem kary, „Nowe Prawo” 1969, nr 2, s. 208.

$44 \mathrm{Na}$ temat sprawiedliwości wyroku zob. J. Skorupka, O sprawiedliwości procesu karnego, Warszawa 2013, s. 326-330.

45 Warto przy tym nadmienić, że w orzecznictwie sformułowano pogląd, iż już sama ,,[...] limitująca funkcja winy zabezpiecza przed orzekaniem kar »niesprawiedliwych « i w tym zakresie ma rolę priorytetową w hierarchii dyrektyw wymiaru kary”. Por. Wyrok Sądu Apelacyjnego w Krakowie z dnia 30 czerwca 2011 r., II AKa 107/11, „Krakowskie Zeszyty Sądowe” 2011, nr 9, poz. 42 . 
potrzeb"46. Nie deprecjonując przy tym znaczenia wymienionych okoliczności prognostycznych dla procesu sądowego wymiaru kary, w zaprezentowanym stanowisku podkreślono jednak, że nie stanowią one czynników natury sprawiedliwościowej ${ }^{47}$.

$\mathrm{Na}$ odmiennych założeniach opierała się natomiast konstrukcja kary sprawiedliwej sensu stricto. Jako punkt wyjścia dla procesu sądowego wymiaru kary uznano bowiem uwzględnienie dwóch jego dyrektyw: stopnia winy oraz stopnia społecznej szkodliwości czynu, które wyznaczałyby ogólne granice kary sprawiedliwej ${ }^{48}$. Wspomniane wskazania ustawowe miałyby bowiem zapewniać dotarcie do sedna problemu odpowiedzialności określanego przez pryzmat czynu zabronionego, a nie osobowości sprawcy. Przy takim założeniu wymierzana sprawcy kara $^{49}$ przybierałaby postać sprawiedliwego odwetu podlegającego następnie sui generis „modyfikacjom”, jakie oferowałyby względy natury prewencyjnej ${ }^{50}$. Za szczególnie istotne uznano przy tym prawidłowe wyważenie racji indywidualnoprewencyjnych, co sumarycznie powinno przyczynić się do pozyskania aprobaty społecznej wobec stosowanych reakcji karnoprawnych, jak również do budowania w nim poczucia zaufania do organów wymiaru sprawiedliwości (co w istocie korelowałoby z ideą pozytywnej prewencji ogólnej $)^{51}$. Zaprezentowane ujęcie odpowiadałoby więc formule, iż: „Karzemy sprawiedliwie, ponieważ popełniono przestępstwo (punitur quia peccatum est) i po to, aby w przyszłości nie popełniano przestępstw (et nec peccetur)" 52 . Warto przy tym nadmienić, że rozważana tutaj wykładania kary sprawiedliwej pozostawała koherentna z poglądami tej części

46 B. Janiszewski, ,Sprawiedliwość” kary. Rozważania wświetle prawnych podstaw jej wymiaru, [w:] Rozważania o prawie karnym. Księga pamiatkowa z okazji siedemdziesięciolecia urodzin Profesora Aleksandra Ratajczaka, red. A.J. Szwarc, Poznań 1999, s. 163, 167; por. także R. Kaczor, Dyrektywa prewencji indywidualnej a idea kary sprawiedliwej, „Probacja” 2009, nr 1, s. 57-58.

47 B. Janiszewski, ,, Sprawiedliwość” kary..., s. 163; por. także V. Konarska-Wrzosek, op. cit., s. 69; zob. również W. Sadurski, Teoria sprawiedliwości, Warszawa 1988, s. 120 n.; R. Kaczor, Dyrektywa prewencji..., s. 59, 61; J.M. Iwaniec, Kara celowa a kara sprawiedliwa, „Przegląd Sądowy” 2004, nr 1, s. 141; M. Szczepaniec, J. Zygmunt, Zasada proporcjonalności na płaszczyźnie wymiaru kary, [w:] Zasada proporcjonalności w prawie karnym, red. T. Dukiet-Nagórska, Warszawa 2010, s. 377.

48 Por. Z. Sienkiewicz, [w:] M. Bojarski, J. Giezek, Z. Sienkiewicz, Prawo karne materialne. Część ogólna i szczególna, red. nauk. M. Bojarski, Warszawa 2004, s. 335; por. także Z. Sienkiewicz, [w:] M. Kalitowski et al., Kodeks karny. Komentarz, t. 3, Gdańsk 1999, s. 93.

49 Por. R. Kaczor, Dyrektywa prewencji.., s. 62.

50 R. Kaczor, Uwagi o celach kary na tle art. 53 \& 1 kodeksu karnego, „Nowa Kodyfikacja Prawa Karnego” 2002, t. 10, s. 44; idem, Sprawiedliwość czy skuteczność kary, „Rzeczpospolita”, 8.12.2010 r.

51 Jednocześnie należy zaznaczyć, że tak pojmowany wymiar kary sprawiedliwej wymaga przestrzegania i harmonizacji całości regulacji części ogólnej kodeksu karnego, normujących wskazaną problematykę. Por. Wyrok Sądu Apelacyjnego we Wrocławiu z dnia 6 maja 2005 r., II Aka 112/05, „Orzecznictwo Sądu Apelacyjnego we Wrocławiu” 2007, nr 1, poz. 3.

52 Por. F. Ciepły, Cele kary w świetle nauczania Jana Pawta II, [w:] Osoba i dzieło Ojca Świętego Jana Pawła II, red. P. Marzec, J. Nikołajew, Tomaszów Lubelski-Lublin 2009, s. 89 n. 
doktryny, która przeciwstawiła się nie tylko wysublimowaniu nadrzędnej czy też inaczej mówiąc, priorytetowej dyrektywy sądowego wymiaru kary ${ }^{53}$, lecz także propagowaniu zachowania „odpowiedniości” pomiędzy dolegliwością kary a stopniem społecznej szkodliwości czynu i winy ${ }^{54}$. Ponadto z powyższych ustaleń wynika także, iż niniejsza „procedura” precyzująca „sprawiedliwościowy” sens kary kryminalnej stawia w wątpliwym świetle rolę dyrektywy pozytywnej prewencji ogólnej w tym zakresie. Wydaje się bowiem, że normatywne sformułowanie nawiązujące do postulatu kształtowania świadomości prawnej społeczeństwa stanowi w swej istocie tautologię, skoro wymierzana sprawiedliwie kara (w oparciu o wspomniane powyżej trzy dyrektywy) będzie per se realizowała wskazany cel ${ }^{55}$.

Omówiona powyżej sui generis „metoda” wyznaczania kary sprawiedliwej nie okazała się również w pełni bezkonkurencyjna. Kolejną propozycję interpretacyjną stanowiła bowiem tzw. szeroka wykładnia (sensu largo) kary sprawiedliwej. Zgodnie z założeniami wspomnianej koncepcji jej istotę odzwierciedlałaby taka kara, która - niekoniecznie czyniąc zadość wszystkim dyrektywom sądowego jej wymiaru — ,[...] należycie uwzględnia rodzaj popełnionego przestępstwa i jego skutki, okoliczności jego popełnienia (typowe i nadzwyczajne), osobowość jego sprawcy, jego właściwości i warunki oraz osobistą sytuację rodziny, przede wszystkim zaś stopień winy oraz ujemną zawartość bezprawia czynu, [...] a nadto zachowanie się sprawcy po popełnieniu przestępstwa, w szczególności próbę naprawienia szkody, pogodzenia się z pokrzywdzonym w wyniku mediacji ${ }^{56}$. Powyższe wyliczenie uzupełniano ponadto koniecznością uwzględnienia ogółu ujemnych następstw dla sprawcy czynu, jakie wynikły dla niego m.in. z przepisów prawnych, jak również norm moralnych czy społecznych. W świetle przedstawio-

53 Tak m.in. Z. Sienkiewicz, Spoleczne niebezpieczeństwo czynu jako dyrektywa sądowego wymiaru kary (na tle teorii i praktyki sądowej), Wrocław 1977, s. 97-98; por. także T. Kaczmarek, Ogólne dyrektywy wymiaru kary w teorii i praktyce sądowej, Wrocław 1980, s. 73-77.

54 Por. T. Kaczmarek, Gtos w dyskusji poświęconej art. 53 k.k., „Czasopismo Prawa Karnego i Nauk Penalnych" 2003, nr 1, s. 102. Odmiennie natomiast T. Bojarski, por. T. Bojarski, Uwagi o karach i ich orzekaniu na tle projektowych zmian kodeksu karnego, [w:] Nauka wobec wspótczesnych zagadnień prawa karnego w Polsce. Księga pamiatkowa ofiarowana Profesorowi Aleksandrowi Tobisowi, red. B. Janiszewski, Poznań 2004, s. 39.

55 Por. Wyrok Sądu Apelacyjnego w Krakowie z dnia 15 stycznia 2003 r., II AKa 360/02, „Prokuratura i Prawo. Dodatek Orzecznictwo” 2009, nr 9, poz. 19; por. także K. Buchała, Problemy wyboru wiodącej dyrektywy..., s. 11; S. Mir Puig, Die begründende und begrenzende Funktion der positiven Generalprävention, „Zeitschrift für die gesamte Strafrechtswissenschaft” nr. 102, 1990, z. 4, s. 922; H. Marquardt, O teoretycznym i praktycznym znaczeniu celów kary w zachodnio-niemieckim prawie karnym, [w:] Teoretyczne problemy odpowiedzialności karnej w polskim oraz niemieckim prawie karnym. Materiaty Polsko-Niemieckiego Sympozjum Prawa Karnego, Karpacz maj 1990, red. T. Kaczmarek, Wrocław 1990, s. 128; S. Waltoś, Proces karny. Zarys systemu, Warszawa 2001, s. 520; I. Andrejew, Polskie prawo karne, Warszawa 1973, s. 234; I. Andrejew, W. Świda, W. Wolter, Kodeks karny z komentarzem, Warszawa 1973, s. 229; B. Wróblewski, Zarys polityki karnej, Wilno 1928, s. 47 n.; K. Buchała, Koncepcja polityki kryminalnej w pracach Bronisława Wróblewskiego, „Studia Prawnicze” 1983, z. 3, s. 17.

56 Por. K. Buchała, [w:] K. Buchała, A. Zoll, Kodeks karny..., s. 379-380. 
nej interpretacji pojęcie kary sprawiedliwej wymagałoby więc starannego rozważenia, jak się wydaje, wszystkich ustawowych wskazań jej wymiaru, co finalnie utwierdzałoby w przekonaniu, że właśnie w ten sposób: „[...] Temida starannie waży wszelkie okoliczności czynu"57. Osławiona opaska na oczach mitycznej bogini nie powinna tym samym sugerować, że zasięg jej wzroku ogranicza się do trzymanych w ręku atrybutów, lecz przekonywać, że ogarnia nim bezstronne, sprawiedliwe ważenie czynów ludzkich, pozwalając dostrzec w osądzonym „odzyskanego człowieka"58. W świetle tego ujęcia wykładnia „kary sprawiedliwej” nie ograniczałaby się tylko do ścisłej analizy postanowień wynikających z ogólnych dyrektyw (art. $53 \S 1$ k.k.), lecz także wymagałaby uwzględnienia pozostałych wskazań sądowego wymiaru kary ${ }^{59}$.

Z perspektywy ogólnych standardów karania wydaje się, że ostatnie z zaprezentowanych stanowisk zasługiwałoby na aprobatę ${ }^{60}$. Zaakcentowany za jego pośrednictwem postulat kompleksowego rozpoznania czynu oraz osoby sprawcy mógłby, przynajmniej w pewnym założeniu, stwarzać gwarancje dla uzyskania sprawiedliwego rozstrzygnięcia ${ }^{61}$.

57 Por. S. Zabłocki, Glosa do wyroku Sądu Najwyższego z dnia 22 III 1974, IV KRN 6/74, „Państwo i Prawo” 1975, nr 10, s. 180-181.

58 Por. I. Dziekońska, Kara, Warszawa 1963, s. 7.

59 W tym zakresie na uwagę zasługuje regulacja art. 85a k.k. określająca expressis verbis dyrektywy wymiaru kary łącznej. Brzmienie przepisu potwierdza przy tym już wcześniej wysuwane w literaturze przedmiotu poglądy, że stopień winy i społecznej szkodliwości poszczególnych przestępstw nie powinny być w tym zakresie brane pod uwagę. W podniesionej argumentacji przekonywano bowiem, że dyrektywy te zostały już w istocie uwzględnione przy wymiarze kar jednostkowych, zaś ponowne kierowanie się nimi oznaczałoby dwukrotne osądzenie tego samego czynu. Zob. m.in. Wyrok Sądu Najwyższego z dnia 25 października 1983 r., IV KR 213/83, OSNKW 1984, nr 5-6, poz. 65; Wyrok Sądu Apelacyjnego w Katowicach z dnia 26 lipca 2007 r., II AKA 186/07, Legalis nr 90157; Wyrok Sądu Apelacyjnego w Rzeszowie z dnia 14 marca 2013 r., II AKA 16/13, Legalis nr 734853; por. także M. Szewczyk, Kara łączna w polskim prawie karnym, Kraków 1981, s. 85-86; por. także K. Buchała, Wymiar kary łącznej, „Państwo i Prawo” 1972, nr 1, s. 60 n.; por. także Wyrok Sądu Apelacyjnego w Krakowie z dnia 18 kwietnia 1991 r., II Akr 33/91, „Krakowskie Zeszyty Sądowe" nr 4, poz. 9 oraz Wyrok Sądu Najwyższego z dnia 28 listopada 1990 r., II KR 61/90, OSP 1991, nr 11, poz. 292; por. również J. Giezek, [w:] J. Giezek, N. Kłączyńska, G. Łabuda, Kodeks karny..., s. 395-396; idem, Dyrektywy wymiaru kary łacznej, [w:] Dyrektywy sądowego wymiaru kary, red. J. Majewski, Warszawa 2014, s. 49-64; A. Barczak-Oplustil, Dyrektywy wymiaru kary łacznej, [w:] Zagadnienia teorii i nauczania prawa karnego. Kara łącza. Ksiega Jubileuszowa Profesor Marii Szewczyk, red. W. Górowski et al., Warszawa 2013, s. 462 n.; M. Lubelski, Zasady i dyrektywy wymiaru kary (rozstrzygnięć o karze i środkach karnych) — próba ujęcia systemowego, [w:] Zagadnienia teorii i nauczania prawa karnego...., s. 238 n.

60 Warto jednak nadmienić, że w literaturze przedmiotu nie zabrakło krytycznych stanowisk wyrażonych pod adresem ustawowych wskazań dla sądowego wymiaru. Na uwagę zasługują zwłaszcza poglądy T. Kaczmarka, który przestrzegał przed zbyt pochopnym przecenianiem ustawowych wskazań sądowego wymiaru kary. Por. T. Kaczmarek, O pozytywnej prewencji..., s. $63 \mathrm{n}$.

61 Na odrębną zaś uwagę zasługuje regulacja art. 56 k.k., która nakazuje „odpowiednie” stosowanie kodeksowych wskazań sądowego wymiaru kary do innych niż kary środków reakcji penalnej. Warto w tym miejscu nadmienić, iż w piśmiennictwie zakwestionowano m.in. doniosłość 


\section{Uwagi końcowe}

Powyższe rozważania potwierdziły niewątpliwie drażliwość oraz złożoność idei sprawiedliwego karania. Wątpliwości te potęguje nie tylko problematyczna wykładnia ustawowych wskazań sądowego wymiaru kary, ale także brak jednoznacznych poglądów pozwalających na ustalenie, jakie okoliczności kodeksowe mają wpływ na wymiar kary i kiedy wymierzoną na ich podstawie karę będzie można uznać za optymalną. Jednocześnie warto $\mathrm{w}$ tym miejscu nadmienić, że poszukiwanie ewentualnego panaceum na pojawiające się w sposób nieuchronny trudności interpretacyjne w postaci konstruowania ścisłych, podręcznikowych definicji sprawiedliwość karania pozostaje zdecydowanie chybionym zabiegiem. Można wręcz przypuszczać, że już samo wyobrażenie o istnieniu podstaw dla wysuwania tego rodzaju schematów, pretendujących następnie do uznania ich powszechnej akceptowalności, raziłoby per se arbitralnością ${ }^{62}$.

\section{A just punishment from the perspective of the laws indicating its measure. Comments in the context of the Penal Code}

\section{Summary}

The subject of this article concerns the issue of fair sentencing. In order to introduce the essence of a just punishment, the study presents its three models, which have been established with a great contribution of the achievements of criminal law and case law. While highlighting these models, the main focus was placed on the selection of statutory indications that should be helpful in making legitimate judicial decision on penalty measure. The observations suggest that the most convincing viewpoint seems to be the stance in light of which the interpretation of "just punishment" should not

oddziaływania ogólnoprewncyjnego w przypadku zakazu prowadzenia pojazdów. Por. K. Łucarz, Zakaz prowadzenia pojazdów jako środek polityki karnej, Wrocław 2005, s. 97. Ponadto wyrażono także przekonanie, że ogółowi zasad i dyrektyw rządzących wymiarem kary nie podlegają, ze swej istoty, środki zabezpieczające. Por. V. Konarska-Wrzosek, op. cit., s. 68. Podobne uwagi należy odnieść do środków probacyjnych. Przykładowo w stosunku do warunkowego przedterminowego zwolnienia nie będzie miał zastosowania zakaz przekraczania stopnia winy. Por. także uwagi J. Lachowskiego; J. Lachowski, Wybrane zagadnienia sporne na tle wykładni przepisów o warunkowym zwolnieniu, [w:] Środki zwiazane z poddaniem sprawcy próbie, red. J. Majewski, Torun 2013, s. 118; idem, Warunkowe przedterminowe zwolnienie $w$ prawie polskim na tle ustawodawstwa państw Rady Europy, X lat obowiazywania kodeksu karnego wykonawczego, red. S. Lelental, G.B. Szczygieł, Białystok 2009, s. 224; idem, Warunkowe zwolnienie z reszty kary pozbawienia wolności, Warszawa 2010, s. 143-145. W tym miejscu należy również wspomnieć, że zgodnie z nowelizacją z dnia 20 lutego 2015 r. (Dz.U., poz. 396) „odpowiednie” stosowanie tego przepisu nie będzie dotyczyło obowiązku naprawienia wyrządzonej przestępstwem szkody lub zadośćuczynienia za doznaną krzywdę. Zgodnie bowiem z nowym brzmieniem art. 46 § 1 k.k. obowiązek ten podlega reżimowi przepisów prawa cywilnego.

62 Por. M. Łoś-Bobińska, op. cit., s. 177. 
be limited to a strict analysis of the provisions under the general directives (Art. $53 \S 1$ of the Polish Penal Code), but must take into account other indications for judicial sentencing. In addition, the fact that the subject of this article is very sensitive also leads to the conclusion that any attempts to create a textbook definition of a just punishment are doomed to fail.

Keywords: judicial sentencing, principle of the degree of guilt, justice, just punishment, general prevention directive.

\section{Bibliografia}

Ajdukiewicz K., O sprawiedliwości, [w:] idem, Język i poznanie, t. 1, Warszawa 1960.

Andrejew I., Polskie prawo karne, Warszawa 1973.

Andrejew I., Świda W., Wolter W., Kodeks karny z komentarzem, Warszawa 1973.

Arystoteles, Etyka nikomachejska, Warszawa 2011.

Augustyniak M., Sprawiedliwość w myśli Arystotelesa, [w:] Sprawiedliwość. Wybrane koncepcje, red. B. Kruszewska, P. Polaczuk, L. Świto, Olsztyn 2010.

Barczak-Oplustil A., Dyrektywy wymiaru kary łącznej, [w:] Zagadnienia teorii i nauczania prawa karnego. Kara łączna. Księga Jubileuszowa Profesor Marii Szewczyk, red. W. Górowski et al., Warszawa 2013.

Błaszczyk M. et al., Kodeks karny. Część ogólna. Komentarz do art. 32-116, t. 2, red. M. Królikowski, R. Zawłocki, Warszawa 2010.

Bojarski T., Społeczna szkodliwość czynu i wina w projekcie k.k., [w:] Problemy kodyfikacji prawa karnego. Księga ku czci Profesora Mariana Cieślaka, red. S. Waltoś, Kraków 1993.

Bojarski T., Uwagi o dalszych projektowanych zmianach części ogólnej kodeksu karnego, [w:] Nowe prawo karne po zmianach, red. T. Bojarski, E. Skrętowicz, Lublin 2002.

Bojarski T., Uwagi o karach i ich orzekaniu na tle projektowych zmian kodeksu karnego, [w:] Nauka wobec wspótczesnych zagadnień prawa karnego w Polsce. Księga pamiatkowa ofiarowana Profesorowi Aleksandrowi Tobisowi, red. B. Janiszewski, Poznań 2004.

Buchała K., Dyrektywy sądowego wymiaru kary, Warszawa 1964.

Buchała K., Głos w dyskusji, [w:] Problemy reformy prawa karnego, red. T. Bojarski, E. Skrętowicz, Lublin 1993.

Buchała K., Koncepcja polityki kryminalnej w pracach Bronisława Wróblewskiego, „Studia Prawnicze" 1983, z. 3.

Buchała K., Ogólne dyrektywy sądowego wymiaru kary w projekcie kodeksu karnego, „Państwo i Prawo" 1969, z. 2.

Buchała K., Problemy wyboru wiodącej dyrektywy wymiaru kary wedtug art. 54 projektu kodeksu karnego z 1995r., „Przegląd Prawa Karnego” 1995, nr 13.

Buchała K., Społeczne niebezpieczeństwo czynu jako dyrektywa sądowego wymiaru kary, „,Krakowskie Zeszyty Prawnicze" 1970, nr 3.

Buchała K., Wymiar kary łacznej, „Państwo i Prawo” 1972, z. 1.

Buchała K., [w:] K. Buchała, A. Zoll, Kodeks karny. Część ogólna. Komentarz, Kraków 2001.

Ciepły F., Cele kary w świetle nauczania Jana Pawła II, [w:] Osoba i dzieło Ojca Świętego Jana Pawła II, red. P. Marzec, J. Nikołajew, Tomaszów Lubelski-Lublin 2009.

Cieślak M., O węzłowych pojęciach zwiazanych z sensem kary, „Nowe Prawo” 1969, nr 2. 
Cieślak M., Polskie prawo karne. Zarys systemowego ujęcia, Warszawa 1994.

Dadak W., Dolegliwość sankcji karnej w czasie orzekania oraz w okresie wykonywania kary, [w:] Państwo prawa i prawo karne. Księga Jubileuszowa Profesora Andrzeja Zolla, Tom 2, red. P. Kardas, T. Sroka, W. Wróbel, Warszawa 2012.

Dąbrowska-Kardas M., Analiza dyrektywalna przepisów części ogólnej kodeksu karnego, Warszawa 2012.

Dziekońska I., Kara, Warszawa 1963.

Gardocki L., Prawo karne, Warszawa 1999.

Giezek J., Dyrektywy wymiaru kary tacznej, [w:] Dyrektywy sadowego wymiaru kary, red. J. Majewski, Warszawa 2014.

Giezek J., Okoliczności wplywające na sędziowski wymiar kary, Wrocław 1989.

Giezek J., [w:] J. Giezek, N. Kłączyńska, G. Łabuda, Kodeks karny. Część ogólna. Komentarz, red. J. Giezek, Warszawa 2012.

Grześkowiak A., Funkcje kary w świetle projektów zmian kodeksu karnego, [w:] Ius et Lex. Księga jubileuszowa ku czci Profesora Adama Strzembosza, red. A. Dębiński, A. Grześkowiak, K. Wiak, Lublin 2002.

Iwaniec J.M., Kara celowa a kara sprawiedliwa, „Przegląd Sądowy” 2004, nr 1.

Janiszewski B., Dolegliwość jako element wspótczesnej kary kryminalnej, [w:] Przestęstwo — kara - polityka kryminalna. Problemy tworzenia i funkcjonowania prawa. Księga jubileuszowa z okazji 70. rocznicy urodzin Profesora Tomasza Kaczmarka, red. J. Giezek, Kraków 2006.

Janiszewski B., „Sprawiedliwość” kary. Rozważania w świetle prawnych podstaw jej wymiaru, [w:] Rozważania o prawie karnym. Księga pamiątkowa z okazji siedemdziesięciolecia urodzin Profesora Aleksandra Ratajczaka, red. A.J. Szwarc, Poznań 1999.

Jescheck H.H., Strafgesetzbuch. Einführung, München 1987.

Jescheck H.H., Weigend T., Lehrbuch des Strafrechts. Allgemeiner Teil, Berlin 1996.

Kaczmarek T., Gtos w dyskusji poświęconej art. 53 k.k., „Czasopismo Prawa Karnego i Nauk Penalnych" 2003, nr 1 .

Kaczmarek T., Ogólne dyrektywy wymiaru kary jako problem kodyfikacyjny, [w:] Problemy reformy prawa karnego, red. T. Bojarski, E. Skrętowicz, Lublin 1993.

Kaczmarek T., Ogólne dyrektywy wymiaru kary w teorii i praktyce sadowej, Wrocław 1980.

Kaczmarek T., O pozytywnej prewencji ogólnej w ujęciu projektu kodeksu karnego z 1994 r., „Palestra" 1995, nr 3-4.

Kaczmarek T., Sędziowski wymiar kary w Polskiej Rzeczpospolitej Ludowej w świetle badań ankietowych, Wrocław 1972.

Kaczor R., Dyrektywa prewencji indywidualnej a idea kary sprawiedliwej, „Probacja” 2009, nr 1.

Kaczor R., Sprawiedliwość czy skuteczność kary, „Rzeczpospolita”, 8.12.2010 r.

Kaczor R., Uwagi o celach kary na tle art. 53 § 1 kodeksu karnego, „Nowa Kodyfikacja Prawa Karnego" 2002, t. 10.

Kalitowski M. et al., Kodeks karny. Komentarz, t. 3, Gdańsk 1999.

Karolak S.J., Sprawiedliwość. Sens prawa. Eseje, Kraków 2005.

Karp J., Sprawiedliwość społeczna. Szkice ze wspótczesnej teorii konstytucjonalizmu i praktyki polskiego prawa ustrojowego, Kraków 2004.

Konarska-Wrzosek V., Dyrektywy wyboru kary w polskim ustawodawstwie karnym, Torun 2002.

Kulesza J., Negatywna prewencja generalna, „Państwo i Prawo” 2011, z. 1.

Lachowski J., Warunkowe przedterminowe zwolnienie $w$ prawie polskim na tle ustawodawstwa państw Rady Europy, X lat obowiazywania kodeksu karnego wykonawczego, red. S. Lelental, G.B. Szczygieł, Białystok 2009.

Prawo 320, 2016

(C) for this edition by CNS 
Lachowski J., Warunkowe zwolnienie z reszty kary pozbawienia wolności, Warszawa 2010.

Lachowski J., Wybrane zagadnienia sporne na tle wykladni przepisów o warunkowym zwolnieniu, [w:] Środki związane z poddaniem sprawcy próbie, red. J. Majewski, Torun 2013.

Lubelski M., Zasady i dyrektywy wymiaru kary (rozstrzygnięć o karze i środkach karnych) — próba ujęcia systemowego, [w:] Zagadnienia teorii i nauczania prawa karnego. Kara taczna. Księga Jubileuszowa Profesor Marii Szewczyk, red. W. Górowski et al., Warszawa 2013.

Łoś-Bobińska M., Zasady wymiaru sprawiedliwości w świetle badań ankietowych, „Etyka” 1968, $\mathrm{nr} 3$.

Łucarz K., Zakaz prowadzenia pojazdów jako środek polityki karnej, Wrocław 2005.

Marek A., Prawo karne, Warszawa 2003.

Mącior W., Kara dostosowana do stopnia winy sprawcy, „Rzeczpospolita”, 28.05.2003 r.

Mącior W., W sprawie reformy prawa karnego, „Państwo i Prawo” 1991, z. 10.

Mącior W., Założenia polityki karnej w projekcie kodeksu karnego z 1995 r., „Przegląd Sądowy” 1996, nr 9.

Marquardt H., O teoretycznym i praktycznym znaczeniu celów kary w zachodnio-niemieckim prawie karnym, [w:] Teoretyczne problemy odpowiedzialności karnej w polskim oraz niemieckim prawie karnym. Materiaty Polsko-Niemieckiego Sympozjum Prawa Karnego, Karpacz maj 1990, red. T. Kaczmarek, Wrocław 1990.

Mir Puig S., Die begründende und begrenzende Funktion der positiven Generalprävention, „Zeitschrift für die gesamte Strafrechtswissenschaft" 102, 1990, z. 4.

Nowe kodeksy karne z 1997 r. z uzasadnieniem, Warszawa 1997.

Orczykowski T., Szkoła psychologiczna w prawie, Torun 2007.

Perelman A., O sprawiedliwości, przeł. W. Bieńkowska, Warszawa 1959.

Płatek M., Rola prawa karnego wykonawczego w zapobieganiu przestępczości, „Studia Iuridica” 2000, t. 38, s. 111.

Sadurski W., Teoria sprawiedliwości, Warszawa 1988.

Sienkiewicz Z., Społeczne niebezpieczeństwo czynu jako dyrektywa sądowego wymiaru kary (na tle teorii i praktyki sadowej), Wrocław 1977.

Sienkiewicz Z., [w:] M. Bojarski, J. Giezek, Z. Sienkiewicz, Prawo karne materialne. Część ogólna i szczególna, red. M. Bojarski, Warszawa 2004.

Skorupka J., O sprawiedliwości procesu karnego, Warszawa 2013.

Skowroński K., Nie bójmy się zaufać sędziom, „Rzeczpospolita”, 25.07.2003 r.

Sylwestrzak A., Filozofia sprawiedliwości Hansa Kelsena, [w:] Doktryny polityczne i prawne u progu XXI wieku, red. M. Maciejewski, M. Marszał, Wrocław 2002.

Szamota-Saeki B., Pozytywna prewencja ogólna w nauce niemieckiej, „Archiwum Kryminologii” 2003-2004, t. 27.

Szczepaniec M., Zygmunt J., Zasada proporcjonalności na płaszczyźnie wymiaru kary, [w:] Zasada proporcjonalności w prawie karnym, red. T. Dukiet-Nagórska, Warszawa 2010.

Szerer M., Problematyka społecznego oddziaływania kary, „Państwo i Prawo” 1974, nr 5.

Szewczyk M., Kara łączna w polskim prawie karnym, Kraków 1981.

Uzasadnienie do projektu rządowego zmiany k.p.k. Reforma procedury karnej, „Demokratyczny Przegląd Prawniczy" 1949, nr 6-7.

Waltoś S., Proces karny. Zarys systemu, Warszawa 2001.

Wolter W., Zasady wymiaru kary w kodeksie karnym z 1969 r., „Państwo i Prawo” 1967, nr 10.

Wróbel W., Nagminność przestęstwa w systemie dyrektyw sądowego wymiaru kary, „Państwo i Prawo" $1990, \mathrm{nr} 3$.

Wróblewski B., Zarys polityki karnej, Wilno 1928.

Wróblewski J., Wartości a decyzja sądowa, Wrocław, 1973.

Zabłocki S., Glosa do wyroku Sądu Najwyższego z dn. 22 III 1974, IV KRN 6/74, „Państwo i Prawo” 1975, nr 10. 
Zalewska M., Racjonalne koncepcje sprawiedliwości w ocenie Hansa Kelsena, [w:] Rozdroża sprawiedliwości we współczesnej myśli filozoficznoprawnej, red. B. Wojciechowski, M.J. Golecki, Torun 2008.

Ziembiński Z., O pojmowaniu sprawiedliwości, Lublin 1992.

Zoll A., O reformie prawa karnego (W odpowiedzi W. Mąciorowi), „Państwo i Prawo” 1992, nr 1.

Zoll A., Stopień społecznego niebezpieczeństwa czynu jako dyrektywa wymiaru kary, „Nowe Prawo" 1969 , nr 6.

Zoll A., Wina i kara, „Nauka” 2004, nr 1.

Zoll A., Założenia polityki karnej w projekcie kodeksu karnego, „Państwo i Prawo” 1994, nr 5. 